\title{
Thermochemical pre- and biological co-treatments to improve hydrolysis and methane production from poultry litter
}

\author{
J.C. Costa *, S.G. Barbosa, M.M. Alves, D.Z. Sousa \\ Institute for Biotechnology and Bioengineering (IBB), Centre of Biological Engineering, University of Minho, 4710-057 Braga, Portugal
}

\section{A R T I C L E I N F O}

Article history:

Received 24 November 2011

Received in revised form 6 February 2012

Accepted 10 February 2012

Available online 17 February 2012

\section{Keywords:}

Biochemical methane potential

Hydrolysis

Lignocellulosic biomass

Poultry litter

Waste treatment

\begin{abstract}
A B S T R A C T
The biochemical methane potential (BMP) of raw poultry litter waste was assessed in batch assays. Biological co-treatment with Clostridium cellulolyticum, Caldicellulosiruptor saccharolyticum and Clostridium thermocellum as bioaugmentation strains, and thermochemical pre-treatments with lime and sodium hydroxide performed at different temperatures and pressures were applied as strategies to improve the BMP by favouring the hydrolysis of the cellulolytic material in the waste. Anaerobic digestion of the raw waste allowed a specific methane production of $145 \pm 14 \mathrm{~L} \mathrm{CH}_{4} \mathrm{~kg}^{-1} \mathrm{VS}$, with $1 \%$ total solids and $0.72 \mathrm{~g} \mathrm{VS}_{\text {inoculum }} \mathrm{g}^{-1} \mathrm{VS}_{\text {waste. }}$ The pre- and co-treatments contributed to a significant increase (up to $74 \%$ ) in the waste solubilisation when using $C$. saccharolyticum, but methane production did not improve considerably. Therefore, the conversion of soluble organic matter to methane was the limiting step of the anaerobic digestion process of poultry litter waste.
\end{abstract}

(c) 2012 Elsevier Ltd. All rights reserved.

\section{Introduction}

Over the past few years, the spread of the economical crises led to a sharp demand for cheaper meat products, such as poultry meat and poultry derivates. As a result, poultry industry is producing increasing amounts of organic wastes, e.g. poultry litter (mixture of manure and bedding material), waste feed, dead birds, blood, broken eggs, and feathers (Kelleher et al., 2002). Current environmental policies and legislation compel poultry industry to adopt effective waste treatment options. Poultry litter is a waste stream of concern because of its high pollutant load. Thus far, composting and direct applications on land have been the most widely used alternatives in handling poultry litter. However, on land overapplication of this material can lead to nutrients leach into the natural environment, with consequences on the spread of pathogens, the production of phytotoxic substances, the eutrophication of water bodies, and also the emission of greenhouse gases and other air pollutants (Kelleher et al., 2002).

Anaerobic digestion of organic wastes is an alternative to waste composting and could be applied to the treatment of poultry litter. Organic material present in poultry litter could be converted to biogas in an anaerobic digestion process. Biogas is a renewable energy carrier, mainly formed by methane $\left(\mathrm{CH}_{4}\right)$ and carbon dioxide $\left(\mathrm{CO}_{2}\right)$. Therefore, this alternative could have an added interest considering the present fossil fuel derived energy limitation and $\mathrm{CO}_{2}$ mitigation

\footnotetext{
* Corresponding author. Tel.: +351 253604 400; fax: +351 253604429 .

E-mail addresses: carloscosta@deb.uminho.pt (J.C. Costa), madalena.alves @deb.uminho.pt (M.M. Alves), dianasous@deb.uminho.pt (D.Z. Sousa).
}

policies (Molinuevo-Salces et al., 2010). Poultry litter can generate more biogas than piggery and cattle wastes (Rao et al., 2011). Nevertheless, poultry litter is a complex substrate containing a high fraction of bedding material, which might include straw, sawdust, wood shavings, shredded paper and peanut or rice hulls. It is generally high in lignocellulose and therefore more recalcitrant to biological degradation (Kelleher et al., 2002; Singh et al., 2010; Mosier et al., 2005). Hydrolysis of lignocellulose has been considered the rate limiting step during anaerobic digestion of this type of waste, thus constraining methane production (Pavlostathis and Giraldo-Gomez, 1991). Pre-treatment of lignocellulosic biomass could accelerate the hydrolysis process and improve the final biogas production from lignocellulosic wastes (Fernandes et al., 2009).

Hydrolysis of lignocelluloses biomass can be stimulated using chemical, thermal, or enzymatic methods. Chemical and thermochemical pre-treatments have been considered unattractive due to the high costs involved, namely regarding the chemicals and energy cost. Lime $\left(\mathrm{Ca}(\mathrm{OH})_{2}\right)$ is an inexpensive and safe to use compound that can be used for alkaline hydrolysis of wastes (alone or in combination with heat and/or pressure). A practical disadvantage is that lime is a weak base and usually a higher concentration or exposure time is necessary to achieve the same performance obtained with strong bases, e.g. sodium hydroxide $(\mathrm{NaOH})$. In previous works it was found that the pre-treatment time, temperature, and lime concentration have greater impacts on digestibility of wastes than water loading and biomass particle size (Chang et al., 2001).

Addition of anaerobic hydrolytic microorganisms can be an alternative for a one-step enhanced hydrolysis-fermentation process. There are several described microorganisms with cellulolytic 
activity that could be used to biodegrade the lignocellulosic portion of poultry litter, namely Clostridium cellulolyticum (Petitdemange et al., 1984) and Caldicellulosiruptor saccharolyticus (VanFossen et al., 2009). Low energy and no chemical requirements are the main advantages of biological pre-treatment. However, the rate of hydrolysis is low in most biological pre-treatment processes (Sun and Cheng, 2002).

The aim of this work was to evaluate the biochemical methane potential (BMP) of poultry litter. Due to the recalcitrance of lignocellulosic materials, bioaugmentation with cellulolytic microorganisms and pre-treatments were applied with the objective of enhancing the waste solubilisation and consequently increase their conversion to methane. Thermochemical pre-treatments, using lime and sodium hydroxide, at high temperature and pressure were tested.

\section{Methods}

\subsection{Waste characterisation}

The waste used in these experiments was collected in a poultry industry in the north of Portugal. The poultry litter had $77 \pm 1.3 \%$ of total solids (TS) and $70 \pm 1.5 \%$ of volatile solids (VS). Chemical oxygen demand (COD) of the waste was $915 \pm 67 \mathrm{~g}$ COD $/ \mathrm{kg}_{\text {waste }}$ and total kjeldahl nitrogen (TKN) was $21 \pm 1 \mathrm{~g} \mathrm{~N} / \mathrm{kg}_{\text {waste }}$ (COD: $\mathrm{N}$ ratio of $44: 1)$. This characterisation resulted from an average of 10 measurements.

\subsection{Anaerobic biodegradability of raw poultry litter}

Anaerobic biodegradability of poultry litter was tested using different concentrations of waste solids, i.e. $1.0 \%, 2.5 \%$ and $5.0 \%$ of $\mathrm{TS}_{\text {waste. }}$ An active anaerobic inoculum (suspended sludge or granular sludge) was added to the tests to a final concentration of $6.6 \mathrm{~g} \mathrm{VS} \mathrm{L}^{-1}$. The ratio inoculum:waste was $0.72,0.29$ and $0.14 \mathrm{~g} \mathrm{VS}_{\text {inoculum }} \mathrm{g}^{-1} \mathrm{VS}_{\text {waste }}$ for the tests with $1.0 \%, 2.5 \%$ and $5.0 \%$ of $\mathrm{TS}_{\text {waste, }}$ respectively. Blank assays without the addition of poultry litter were also performed. Detailed procedure of biodegradability tests in Section 2.5 .

\subsection{Biological co-treatment (bioaugmentation)}

\subsubsection{Medium composition and microorganisms cultivation}

C. cellulolyticum (DSM 5812), Clostridium thermocellum (DSM 1237), and C. saccharolyticus (DSM 8903) used in the bioaugmentation assays were purchased from the Deutsche Sammlung von Mikroorganismen und Zellkulturen GmbH (DSMZ, Braunschweig, Germany). C. cellulolyticum and $C$. thermocellum were pre-grown in CM3 medium using 6 and $5 \mathrm{~g} \mathrm{~L}^{-1}$ of cellobiose as carbon source, respectively. The composition of $\mathrm{CM} 3$ was (per L): yeast extract, $2.0 \mathrm{~g} ; \quad\left(\mathrm{NH}_{4}\right)_{2} \mathrm{SO}_{4}, 1.3 \mathrm{~g} ; \mathrm{KH}_{2} \mathrm{PO}_{4}, 1.5 \mathrm{~g} ; \mathrm{K}_{2} \mathrm{HPO}_{4} \cdot 3 \mathrm{H}_{2} \mathrm{O}, 2.9 \mathrm{~g}$; $\mathrm{MgCl}_{2} \cdot 6 \mathrm{H}_{2} \mathrm{O}, 0.2 \mathrm{~g} ; \mathrm{CaCl}_{2} \cdot 2 \mathrm{H}_{2} \mathrm{O}, 0.075 \mathrm{~g} ; \mathrm{FeSO}_{4} \cdot 7 \mathrm{H}_{2} \mathrm{O}, 1.25 \mathrm{mg}$; resazurin, $0.5 \mathrm{mg}$; cysteine- $\mathrm{HCl} \cdot \mathrm{H}_{2} \mathrm{O}, 0.5 \mathrm{~g}$; trace elements solution SL-10, $1 \mathrm{~mL}$. The trace element solution contained (per L): hydrochloric acid (25\%), $10 \mathrm{~mL} ; \mathrm{FeCl}_{2} \cdot 4 \mathrm{H}_{2} \mathrm{O}, 1.5 \mathrm{~g} ; \mathrm{ZnCl}_{2}, 70 \mathrm{mg}$; $\mathrm{MnCl}_{2} \cdot 4 \mathrm{H}_{2} \mathrm{O}, 100 \mathrm{mg} ; \mathrm{H}_{3} \mathrm{BO}_{3}, 6 \mathrm{mg} ; \mathrm{CoCl}_{2} \cdot 6 \mathrm{H}_{2} \mathrm{O}, 190 \mathrm{mg}$; $\mathrm{CuCl}_{2} \cdot 2 \mathrm{H}_{2} \mathrm{O}, 2 \mathrm{mg}$; $\mathrm{NiCl}_{2} \cdot 6 \mathrm{H}_{2} \mathrm{O}, 24 \mathrm{mg} ; \mathrm{Na}_{2} \mathrm{MoO}_{4} \cdot 2 \mathrm{H}_{2} \mathrm{O}, 36 \mathrm{mg}$. The $\mathrm{pH}$ of the medium was adjusted to 6.0 with hydrochloric acid and dispensed into serum bottles. The bottles were sealed with butyl rubber septa and aluminium crimp caps and the headspace was flushed with $\mathrm{N}_{2}(1.7 \times 105 \mathrm{~Pa})$. After autoclaving, $\mathrm{pH}$ of the medium was adjusted to 7.2 by adding a sterile anoxic $\mathrm{Na}_{2} \mathrm{CO}_{3}$ solution $(5 \% \mathrm{w} / \mathrm{v})$ prepared under a mixture of $\mathrm{N}_{2}: \mathrm{CO}_{2}(80: 20 \%)$. C. cellulolyticum and $C$. thermocellum cultures were incubated shaking (100 rpm) in the dark at 37 or $55^{\circ} \mathrm{C}$, respectively. C. saccharolyticus was pre-grown with $1 \mathrm{~g} \mathrm{~L}^{-1}$ cellobiose in medium containing (per L): yeast extract, $2 \mathrm{~g}$; tripticase, $1.5 \mathrm{~g} ; \mathrm{NH}_{4} \mathrm{Cl}, 0.9 \mathrm{~g} ; \mathrm{NaCl}, 0.9 \mathrm{~g}$; $\mathrm{KH}_{2} \mathrm{PO}_{4}, 0.75 \mathrm{~g} ; \mathrm{K}_{2} \mathrm{HPO}_{4}, 1.5 \mathrm{~g} ; \mathrm{MgCl}_{2} \cdot 6 \mathrm{H}_{2} \mathrm{O}, 0.4 \mathrm{~g} ; \mathrm{FeCl}_{3} \cdot 6 \mathrm{H}_{2} \mathrm{O}$, $2.5 \mathrm{mg}$; resazurin, $0.5 \mathrm{mg}$; cysteine- $\mathrm{HCl} \cdot \mathrm{H}_{2} \mathrm{O}, 0.75 \mathrm{~g}$; trace elements solution SL-10, $1 \mathrm{~mL}$. The $\mathrm{pH}$ of the medium was adjusted to 7.2, dispensed into serum bottles and the bottles' headspace was flushed with $\mathrm{N}_{2}\left(1.7 \times 10^{5} \mathrm{~Pa}\right)$. C. saccharolyticus cultures were incubated shaking $(100 \mathrm{rpm})$ at $65^{\circ} \mathrm{C}$ in the dark.

\subsubsection{Bioaugmented poultry litter biodegradability tests}

C. cellulolyticum, $C$. thermocellum, and C. saccharolyticus cells were harvested during the exponential phase by centrifugation (1500g, $10 \mathrm{~min}$ ); $2.5 \mathrm{~mL}$ of $25 \times$ concentrated cells of each microorganism were used in the anaerobic biodegradability tests containing poultry waste $\left(2.5 \% \mathrm{TS}_{\text {waste }}\right)$ and anaerobic granular sludge (approximately $0.77 \mathrm{~g} \mathrm{VS}_{\text {inoculum }} \mathrm{g}^{-1} \mathrm{VS}_{\text {waste }}$ ). Biodegradability test vials were incubated at the optimal temperature of each microorganism, i.e. 37,55 , and $65^{\circ} \mathrm{C}$ for $C$. cellulolyticum, C. thermocellum, and $C$. saccharolyticus, respectively. Controls, in which each of the microorganisms was incubated with poultry litter, but without anaerobic sludge, were also performed. Non-bioaugmented vials, containing waste and anaerobic sludge, were also set-up. Biodegradability tests procedure in Section 2.5.

\subsection{Thermochemical pre-treatment}

\subsubsection{Thermochemical pre-treatments}

Poultry litter was pre-treated with two alkali, i.e. lime and sodium hydroxide. Variables tested were: (i) temperature (20 and $\left.90{ }^{\circ} \mathrm{C}\right)$, (ii) contact time $(30,60$ and $120 \mathrm{~min})$, (iii) pressure (1.01, 1.27 and 4 bar), and (iv) base concentration $\left(0.05,0.1\right.$ e $0.2 \mathrm{~g}_{\text {alkali }} /$ $\left.\mathrm{g} \mathrm{TS}_{\text {waste }}\right)$. Thermochemical pre-treatment tests were made using $40 \mathrm{~g} \mathrm{TS}_{\text {waste }} \mathrm{L}^{-1}$. Assays at $90^{\circ} \mathrm{C}$ and with overpressure (1.27 and 4 bar) were performed in an autoclave (Hiclave HV-25L, Dublin, Ireland) and in a pressure column equipped with a pressure transducer and a regulatory valve, respectively. Column pressurisation was made through the injection of $\mathrm{N}_{2}$. Soluble COD concentration $\left(\mathrm{COD}_{\mathrm{s}}\right)$ was determined before and after thermochemical treatment. The percentage of solubilisation in the pre-treatment ( $\left.\mathrm{PS}_{\text {pre-treatment }}\right)$, was calculated as the percentage of the initial COD added to the vials that was solubilized during the thermochemical treatment (Eq. (1)).

$\mathrm{PS}_{\text {pre-treatment }}=\frac{\mathrm{mg} \mathrm{COD}(\text { end pre-treatment })-\mathrm{mg} \mathrm{COD}_{\mathrm{s}}(\text { initial })}{\mathrm{mg} \mathrm{COD}} \times 100$

Thermochemical treatments yielding high percentage of organic matter solubilisation were selected for subsequent biodegradability tests.

2.4.2. Anaerobic biodegradability assays of pre-treated poultry waste Anaerobic biodegradability tests of raw and pre-treated poultry wastes were performed according to the procedure detailed in Section 2.5. Prior to the tests, $\mathrm{pH}$ was neutralized with hydrochloric acid $(8 \mathrm{M})$. The assays were performed with $31.25 \mathrm{~mL}$ of pre-treated sample corresponding to $2.5 \% \mathrm{TS}_{\text {waste, }}$ using a ratio of inoculum:waste of $0.74 \mathrm{~g} \mathrm{VS}_{\text {inoculum }} \mathrm{g}^{-1} \mathrm{VS}_{\text {waste. }}$

\subsection{Anaerobic biodegradability assays}

Anaerobic biodegradability batch tests were used to determine the BMP and maximum methane production rate $(\mathrm{Rm})$ from the poultry wastes. 


\subsubsection{Inoculum source}

Poultry litter without co- or pre-treatment (Section 2.2) was inoculated with anaerobic suspended sludge from a municipal wastewater treatment plant (VS $=13 \pm 1 \mathrm{~g} \mathrm{~L}^{-1}$, Specific Acetoclastic Activity (SAA) $<10 \mathrm{~mL} \mathrm{CH}_{4} @ \mathrm{STP}^{-1} \mathrm{VS} \mathrm{d}^{-1}$, and Specific Hydrogenotrophic Methanogenic Activity (SHMA) $=695 \pm 39 \mathrm{~mL} \mathrm{CH}_{4}$ @STP $\mathrm{g}^{-1} \mathrm{VS} \mathrm{d}^{-1}$ ). The assay with $2.5 \% \mathrm{TS}$ poultry litter was repeated using granular sludge from a brewery industry (VS $=44 \pm 3 \mathrm{~g} \mathrm{~L}^{-1}$; $\mathrm{SAA}=55 \pm 4 \mathrm{~mL} \mathrm{CH}_{4}$ @STP $\mathrm{g}^{-1} \mathrm{VS} \mathrm{d}^{-1} ; \mathrm{SHMA}=655 \pm 39 \mathrm{~mL} \mathrm{CH}_{4}$ @STP $\mathrm{g}^{-1} \mathrm{VS} \mathrm{d}^{-1}$ ), in order to test a more active inoculum. The SAA and SHMA were determined according to Colleran et al. (1992) and Alves et al. (2001). Assay with granular sludge (which has a higher acetoclastic activity than suspended sludge) was done for testing the possibility of accelerating methane production rate, and therefore decrease the time required for BMP testing.

\subsubsection{Experimental procedure}

Biodegradability assays were performed according to the directives defined by Angelidaki et al. (2009). Bottles were prepared by adding the substrate (poultry litter), inoculum (anaerobic sludge), and basal medium containing $\mathrm{NaHCO}_{3}\left(5 \mathrm{~g} \mathrm{~L}^{-1}\right)$ to a final volume of $50 \mathrm{~mL}$. pH of the medium was corrected to 7.0-7.2 with $\mathrm{NaOH}$ or $\mathrm{HCl} 2 \mathrm{M}$. The vials were sealed and the headspace flushed with $\mathrm{N}_{2} / \mathrm{CO}_{2}(80: 20 \mathrm{v} / \mathrm{v})$. Before incubation, the medium was amended with $\mathrm{Na}_{2} \mathrm{~S} \cdot 9 \mathrm{H}_{2} \mathrm{O}$, to a final concentration of $1 \mathrm{mM}$. All batch tests were performed in triplicate and incubated at $37^{\circ} \mathrm{C}$, except for the bioaugmentation tests that were incubated at optimum growth temperature of each microorganism. Blank and control assays were also performed as described in previous sections.

Methane in the vessels headspace was monitored by gas chromatography using $500 \mu \mathrm{L}$ of gas sample collected with a gas-tight syringe. Methane production was corrected for standard temperature and pressure (STP) conditions. BMP was determined by unit of VS of waste added to each vial:

$\mathrm{BMP}=\mathrm{L} \mathrm{CH}_{4} / \mathrm{kg} \mathrm{VS}=\frac{\mathrm{kg} \mathrm{COD}-\mathrm{CH}_{4} \times 350(\mathrm{~L} \mathrm{CH} / \mathrm{kg} \mathrm{COD})}{\mathrm{VS}_{\text {waste }} \text { added }(\mathrm{kg} \mathrm{VS})}$

Relative methane production (MP) was defined as the amount of methane produced during the assays in relation to the theoretical biochemical methane potential (i.e. $350 \mathrm{~L} \mathrm{CH}_{4} / \mathrm{kg} \mathrm{COD}$ ):

$\mathrm{MP}=\frac{\mathrm{mg} \mathrm{COD}-\mathrm{CH}_{4}}{\mathrm{mg} \mathrm{COD}} \times 100$

Hydrolysis extent was evaluated considering the percentage of solubilisation (PS), which is the percentage of the initial COD added to the vials that is solubilized during the anaerobic biodegradability assay (Eq. (4)).

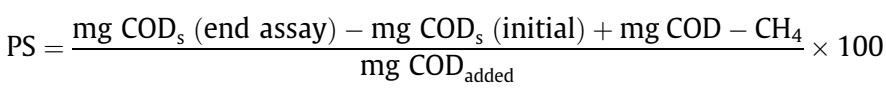

\subsection{Analytical methods}

TKN, TS, and VS were measured according to standard methods (APHA, 1998). Total and soluble COD was determined using standard kits (Hach Lange, Düsseldorf, Germany). Ammonium was determined by the Nessler method (APHA, 1998) and reducing sugars were measured using the 3,5-dinitrosalicylic acid (DNS) method (Miller, 1959). Volatile fatty acids (VFA) were determined by HPLC (Jasco, Japan) equipped with a UV detector $(210 \mathrm{~nm})$ and a Chrompack column $\left(6.5 \times 30 \mathrm{~mm}^{2}\right)$ at $60{ }^{\circ} \mathrm{C}$ and using sulphuric acid $(0.01 \mathrm{~N})$ as mobile phase at a flow rate of $0.6 \mathrm{~mL} / \mathrm{min}$. Methane in biogas was analyzed in a gas chromatograph (Chrompack 9000) equipped with a FID detector and a $2 \mathrm{~m} \times 1 / 8^{\prime \prime}$ Chromosorb 101
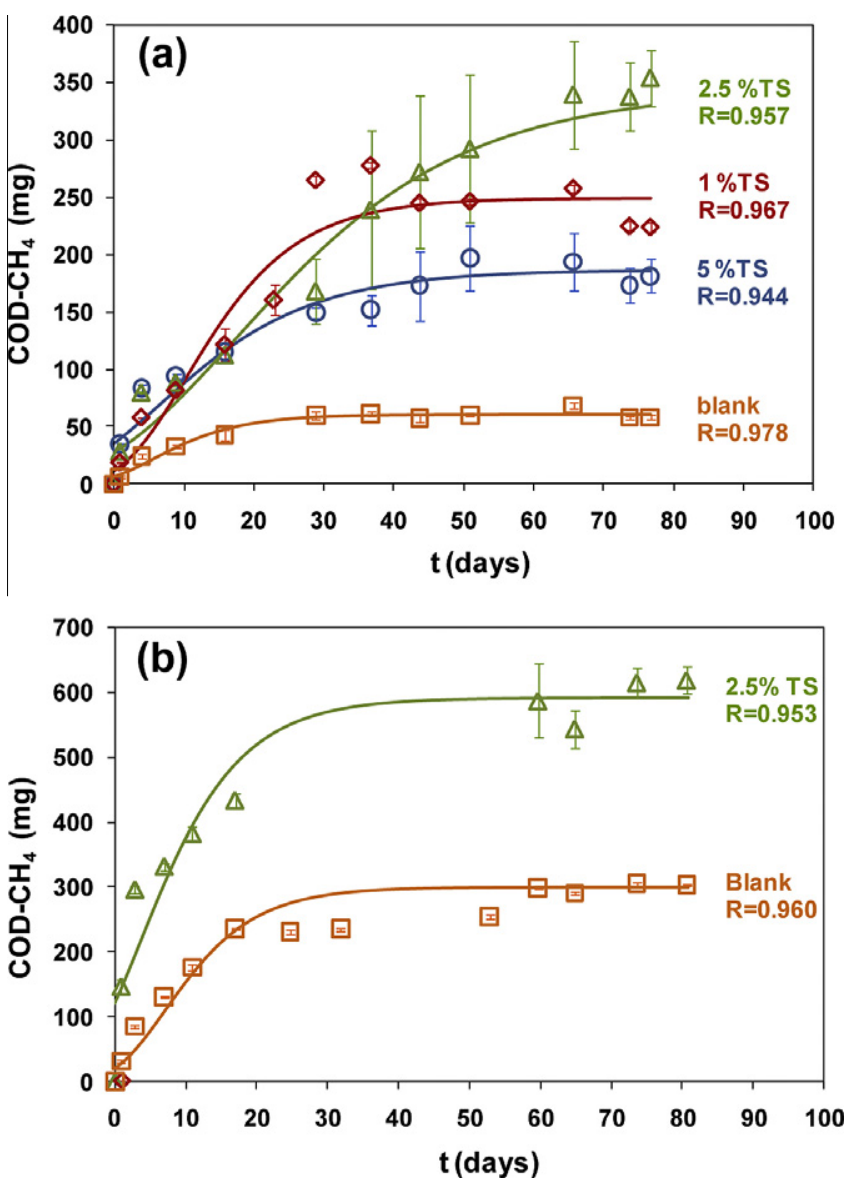

Fig. 1. Cumulative methane production $\left(\mathrm{mg} \mathrm{COD}-\mathrm{CH}_{4}\right)$ during anaerobic biodegradability tests at different poultry litter concentrations with anaerobic suspended sludge (a) and granular sludge (b). $0 \%$ TS (blank) $(\square), 1 \%$ TS $(\diamond), 2.5 \%$ TS $(\triangle)$, and $5 \%$ TS (O). The symbols represent the experimental data with respective standard deviation ( $n=3$ points). The lines represent the predicted data by the modified Gompertz equation.

(80-120 mesh) column and using nitrogen as carrier gas $(30 \mathrm{~mL} /$ $\mathrm{min}$ ); column, injector, and detector temperatures were 35,110 , and $220^{\circ} \mathrm{C}$, respectively.

\subsection{Statistical analysis}

The modified Gompertz equation (Eq. (5)) was used to describe the progress of cumulative methane production obtained from the batch experiments (Zwietering et al., 1990).

$M(t)=P \exp \left[-\exp \left[\frac{R m^{e}}{p}(\lambda-t)+1\right]\right]$

where $M(t)$ is the methane cumulative production (mg COD- $\mathrm{CH}_{4}$ ), $P$ is the maximum methane production ( $\left.\mathrm{mg} \mathrm{COD}-\mathrm{CH}_{4}\right), \mathrm{Rm}$ is the maximum methane production rate ( $\left.\mathrm{mg} \mathrm{COD}-\mathrm{CH}_{4} \mathrm{~d}^{-1}\right), e$ equals to 2.7182818 , and $\lambda$ is the lag-phase (days).

Waste biodegradability results were compared after a significance statistical analysis by using a single factor analysis of variance (ANOVA). Statistical significance was established at the $P<0.05$ level. 
Table 1

Methane-production parameters predicted by the modified Gompertz equation and experimental results obtained at the end of raw poultry wastes biodegradability tests.

\begin{tabular}{|c|c|c|c|c|c|}
\hline & & Suspended & & & Granular \\
\hline Concentration & & $1 \% \mathrm{TS}$ & $2.5 \% \mathrm{TS}$ & $5 \% \mathrm{TS}$ & $2.5 \% \mathrm{TS}$ \\
\hline $\mathrm{g} \mathrm{VS}_{\text {inoculum }} \mathrm{g}^{-1} \mathrm{VS}_{\text {waste }}$ & & 0.72 & 0.29 & 0.14 & 0.77 \\
\hline $\mathrm{P}$ & $\mathrm{mg} \mathrm{COD}-\mathrm{CH}_{4}$ & $188 \pm 20$ & $284 \pm 31$ & $126 \pm 21$ & $292 \pm 45$ \\
\hline BMP & $\mathrm{LCH}_{4} \mathrm{~kg}^{-1} \mathrm{VS}$ & $145 \pm 14$ & $87 \pm 10$ & $19 \pm 3$ & $90 \pm 13$ \\
\hline $\mathrm{Rm}$ & $\mathrm{mg} \mathrm{COD}-\mathrm{CH}_{4} \mathrm{~d}^{-1}$ & 10.1 & 6.7 & 5.5 & 27.3 \\
\hline MP & $\%$ & $31 \pm 3$ & $19 \pm 2$ & $4 \pm 1$ & $17 \pm 2$ \\
\hline PS & $\%$ & $32 \pm 3$ & $34 \pm 2$ & $34 \pm 1$ & $52 \pm 2$ \\
\hline $\mathrm{pH}$ & & 7.6 & 7.5 & 7.0 & 7.3 \\
\hline $\mathrm{COD}_{\mathrm{s}}$ & $\mathrm{g} \mathrm{L}^{-1}$ & $0.66 \pm 0.26$ & $6.00 \pm 1.31$ & $20.94 \pm 0.72$ & $13.98 \pm 1.52$ \\
\hline Sugars & $\mathrm{g} \mathrm{L}^{-1}$ & nd & nd & nd & $1.68 \pm 0.12$ \\
\hline $\mathrm{NH}_{4}^{+}-\mathrm{N}$ & $\mathrm{g} \mathrm{L}^{-1}$ & $0.25 \pm 0.03$ & $0.70 \pm 0.01$ & $1.28 \pm 0.54$ & $0.64 \pm 0.07$ \\
\hline Total VFA & $\operatorname{g~COD~L~}^{-1}$ & 0 & $3.50 \pm 1.18$ & $15.53 \pm 4.49$ & $3.27 \pm 0.47$ \\
\hline Acetic acid & $\mathrm{mg} \mathrm{COD} \mathrm{L} \mathrm{L}^{-1}$ & 0 & 1412 & 5193 & 1427 \\
\hline Propionic acid & $\mathrm{mg} \mathrm{COD} \mathrm{L}^{-1}$ & 0 & 1412 & 3928 & 1557 \\
\hline iso-Butyric acid & $\mathrm{mg} \mathrm{COD} \mathrm{L}^{-1}$ & 0 & 676 & 3808 & 287 \\
\hline$n$-Butyric acid & $\mathrm{mg} \mathrm{COD} \mathrm{L}^{-1}$ & 0 & 0 & 2602 & 0 \\
\hline Ethanol & $\mathrm{mg} \mathrm{COD} \mathrm{L}^{-1}$ & 0 & 177 & 3352 & 3410 \\
\hline Butanol & $\mathrm{mg} \mathrm{COD} \mathrm{L}^{-1}$ & 0 & 0 & 0 & 3898 \\
\hline
\end{tabular}

Note: The values obtained in the blanks were subtracted in the data presented in the table.

nd: Not determined.

Table 2

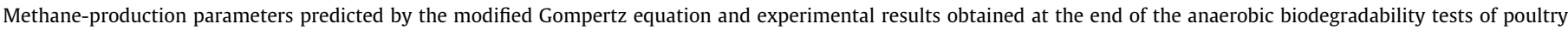
litter (2.5\% TS) bioaugmented with cellulolytic microorganisms.

\begin{tabular}{|c|c|c|c|c|}
\hline & & C. cellulolyticum & C. thermocellum & C. saccharolyticus \\
\hline $\mathrm{P}$ & $\mathrm{mg} \mathrm{COD}-\mathrm{CH}_{4}$ & $335 \pm 17$ & $241 \pm 21$ & $310 \pm 23$ \\
\hline BMP & $\mathrm{LCH}_{4} \mathrm{~kg}^{-1} \mathrm{VS}$ & $102 \pm 5$ & $71 \pm 7$ & $95 \pm 4$ \\
\hline$R m$ & $\mathrm{mg} \mathrm{COD}-\mathrm{CH}_{4} \mathrm{~d}^{-1}$ & 25.2 & 12.3 & 10.5 \\
\hline MP & $\%$ & $23 \pm 1$ & $16 \pm 1$ & $21 \pm 1$ \\
\hline PS & $\%$ & $57 \pm 2$ & $62 \pm 1$ & $74 \pm 1$ \\
\hline $\mathrm{pH}$ & & 7.2 & 7.5 & 7.6 \\
\hline $\mathrm{COD}_{\mathrm{s}}$ & $\mathrm{g} \mathrm{L}^{-1}$ & $11.81 \pm 0.94$ & $15.16 \pm 1.29$ & $17.25 \pm 0.92$ \\
\hline Sugars & $\mathrm{g} \mathrm{L}^{-1}$ & $0.20 \pm 0.07$ & $1.19 \pm 0.18$ & $1.15 \pm 0.22$ \\
\hline $\mathrm{NH}_{4}^{+}-\mathrm{N}$ & $\mathrm{g} \mathrm{L}^{-1}$ & $1.16 \pm 0.46$ & $0.24 \pm 0.06$ & $0.70 \pm 0.04$ \\
\hline Total VFA & $\operatorname{g~COD~L~}^{-1}$ & $4.14 \pm 0.69$ & $8.66 \pm 0.37$ & $6.43 \pm 0.86$ \\
\hline Acetic acid & $\mathrm{mg} \mathrm{COD} \mathrm{L} \mathrm{L}^{-1}$ & 3277 & 4802 & 3251 \\
\hline Propionic acid & $\operatorname{mg~COD~L} L^{-1}$ & 183 & 3246 & 2480 \\
\hline iso-Butyric acid & $\mathrm{mg} \mathrm{COD} \mathrm{L}^{-1}$ & 683 & 598 & 701 \\
\hline n-Butyric acid & $\mathrm{mg} \mathrm{COD} \mathrm{L} \mathrm{L}^{-1}$ & 0 & 0 & 0 \\
\hline
\end{tabular}

Note: The values obtained in the blanks were subtracted in the data presented in the table.

\section{Results and discussion}

\subsection{Biomethane potential of the raw poultry litter}

The first part of this research consisted in assessing the BMP of the raw poultry litter, i.e. without co- or pre-treatment. The profiles of cumulative methane production, using suspended sludge as inoculum, are shown in Fig. 1a. The best scenario in terms of specific methane production was observed for solids concentration of $1 \% \mathrm{TS}$; in this case a maximum specific methane production of $145 \pm 14 \mathrm{~L} \mathrm{CH}_{4} \mathrm{~kg}^{-1}$ VS could be obtained, which corresponds to approximately MP of $41 \pm 3 \%$ (Table 1 ). Specific methane production in the range of $140-220 \mathrm{~L} \mathrm{CH}_{4} \mathrm{~kg}^{-1}$ VS have been reported by other authors (Webb and Hawkes, 1985), but in continuous reactors. According to Bujoczek et al. (2000), anaerobic digestion of chicken manure is feasible up to a solid concentration of $10 \%$ TS. However, in this experiment with poultry litter (a mixture of manure, straw and feathers), an inhibitory effect occurred in the vials with high solids concentration, especially with $5 \%$ TS. This is possibly related with VFA, alcohols and $\mathrm{COD}_{\mathrm{s}}$ accumulation inside the vials, although no drop in the $\mathrm{pH}$ of the medium was observed due to high VFA concentrations (Table 1). Ammonium concentration at the end of the batch assays increased from $0.25 \pm 0.54$ to $1.28 \pm 0.54 \mathrm{~g} \mathrm{NH}_{4}-\mathrm{N} \mathrm{L}^{-1}$ in assays with $1 \%$ and $5 \% \mathrm{TS}$, respectively (Table 1). However, unionized ammonium concentrations detected never reached inhibitory levels, since a maximum of $27.5 \mathrm{mg} \mathrm{NH} \mathrm{N}_{3}$ $\mathrm{N} \mathrm{L}^{-1}$ was obtained for the assay with $2.5 \% \mathrm{TS}$. According to Rao et al. (2008) unionized ammonia in the range of $0.1-1.1 \mathrm{~g} \mathrm{~N} \mathrm{~L}^{-1}$ inhibits methanogenesis.

Since the time required for BMP testing was too long with suspended sludge, a test with granular sludge was also performed. Considering that $1 \%$ TS is a very low solids concentration for practical purposes, it was decided to test the intermediate TS concentration of 2.5\%. As expected, the BMP values obtained for 2.5\% with suspended and granular sludge were similar, but the maximum methane production rate $(\mathrm{Rm})$ was $4 \times$ higher in the assay with granular sludge $\left(27.3 \mathrm{mg}\right.$ COD- $\mathrm{CH}_{4} \mathrm{~d}^{-1}$ vs. $6.7 \mathrm{mg}$ COD$\mathrm{CH}_{4} \mathrm{~d}^{-1}$ ). Percentage of COD solubilisation of the poultry waste was similar for all the tests in which suspended inoculum was used (PS of approximately $34 \%$, for all tested\% $\mathrm{TS}_{\text {waste }}$ ), A higher solubilisation percentage was obtained in the assays with granular sludge and $2.5 \%$ of $\mathrm{TS}_{\text {waste }}$ (i.e. PS of $52 \pm 2 \%$ ). 

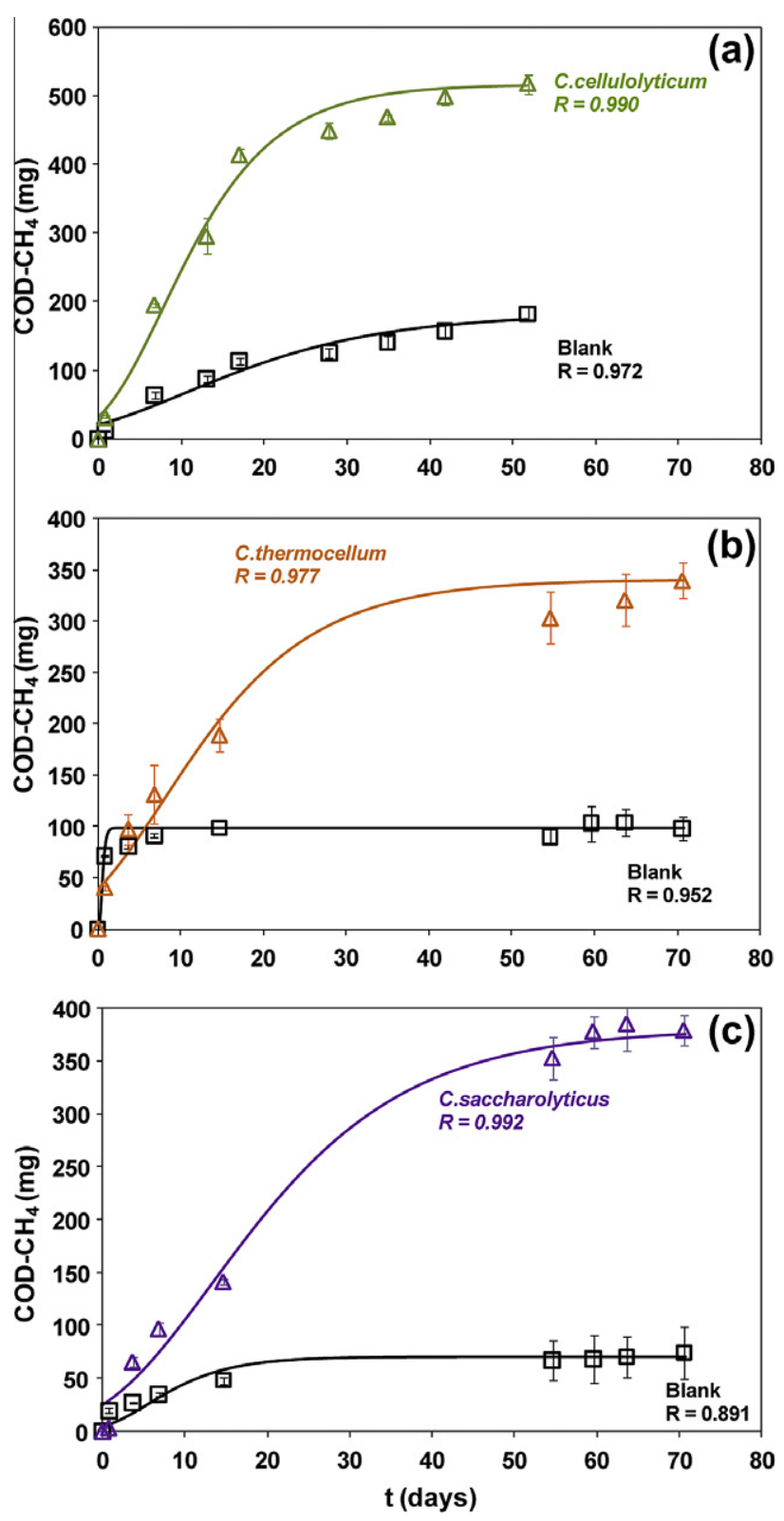

Fig. 2. Cumulative methane production ( $\left.\mathrm{mg} \mathrm{COD}-\mathrm{CH}_{4}\right)$ during anaerobic biodegradability tests of poultry litter bioaugmented with: (a) C. cellulolyticum ( $\triangle$ ); (b) C. thermocellum $(\triangle)$; and, (c) C. saccharolyticus $(\triangle)$. The respective blank assay $(\square)$ without waste and microorganism is presented in all figures. The symbols represent the experimental data with respective standard deviation ( $n=3$ points). The lines represent the predicted data by the modified Gompertz equation.

\subsection{Biological co-treatment (bioaugmentation)}

Results from the bioaugmented tests with mesophilic (C. cellulollyticum) and thermophilic (C. thermocellum and $C$. saccharolyticus) microorganisms are displayed in Table 2. The profiles of cumulative methane production and predicted data by the modified Gompertz equation are presented in Fig. 2.

Addition of $C$. cellulolyticum had a clear positive effect in the cumulative methane production $\left(P=335 \pm 17 \mathrm{mg} C O D-\mathrm{CH}_{4}\right.$, value approximately $15 \%$ higher than in the non-bioaugmented test). Specific methane production in $C$. cellulolyticum bioaugmented test was $102 \pm 5 \mathrm{~L} \mathrm{CH}_{4} \mathrm{~kg}^{-1}$ VS. These results are significantly higher $(P<0.01)$ than the obtained in the raw waste non-bioaugmented tests. VFA concentration increased from $3.27 \pm 0.47 \mathrm{~g} \mathrm{~L}^{-1}$, in non-bioaugmented tests, to $4.14 \pm 0.69 \mathrm{~g} \mathrm{~L}^{-1}$ in $C$. cellulolyticum bioaugmented tests. This might indicate an enhanced hydrolysis and subsequent acidogenesis of the waste material. C. cellulolyticum was isolated from decayed grass and was proven to be capable of hydrolyzing cellulose and fermenting sugars (Petitdemange et al., 1984). Sugars concentration at the end of the assay was lower in C. cellulolyticum bioaugmented tests (i.e. $0.20 \pm 0.07 \mathrm{~g} \mathrm{~L}^{-1}$ ) than in the non-bioaugmented tests (i.e. $1.68 \pm 0.12 \mathrm{~g} \mathrm{~L}^{-1}$ ). Therefore, low sugar concentrations might be related to $C$. cellulolyticum activity.

In the trials with $C$. thermocellum and $C$. saccharolyticus as bioaugmented species no significant differences on methane production were observed, when compared to the non-bioaugmented assays. However, the bioaugmentation with these microorganisms caused a significant increase $(P<0.01)$ in the solubilisation of the organic matter in the waste: PS value in non-bioaugmented tests was $52 \pm 2 \%$, while in C. thermocellum and $C$. saccharolyticus bioaugmented tests PS values were $62 \pm 1 \%$ and $74 \pm 1 \%$, respectively. This indicates an efficient hydrolysis of the cellulosic material in the poultry litter. C. thermocellum is a thermophilic bacterium with high cellulolytic activity that ferments lignocellulosic substrates to mainly hydrogen, acetate and ethanol (Lynd et al., 1989; Weimer and Zeikus, 1977). Nevertheless, some of the by-products generated during hydrolysis accumulated in the medium and were not converted to methane, which indicates that methanogenesis was the rate-limiting step in the conversion of cellulosic material. Apparent low methanogenic activity could be associated to the fact of using a mesophilic methanogenic inoculum for $C$. thermocellum bioaugmentation tests, which were performed at $55^{\circ} \mathrm{C}$. Results with C. saccharolyticus were similar, i.e. higher solubilisation of the organic material present in the poultry waste but no improvement in methane production, when compared with non-bioaugmented assays. Also here incubations were performed at high temperature, i.e. $65^{\circ} \mathrm{C}$, which might have negatively influenced methanogenic archaea present in the inoculum sludge. In the control assays with $2.5 \% \mathrm{TS}_{\text {waste }}$ and bioaugmenting strains, a COD removal of $33 \pm 2 \%$ and $32 \pm 1 \%$ was observed after $120 \mathrm{~h}$ of inoculation with $C$. thermocellum and C.saccharolyticus, respectively. These results confirm that the hydrolytic microorganisms effectively act on the substrate. The results obtained in the co-treatment assays with the three strains suggest that instead of a co-treatment, a two stage strategy consisting in pre-treatment/acidification followed by the methanogenic phase, should be considered in further studies.

\subsection{Biomethane potential of thermochemical pre-treated poultry litter}

Results of waste pre-treatment with lime and sodium hydroxide are summarized in Table 3. In the assays with lime, solubilisation significantly increased with temperature $(P<0.01)$. Soluble COD increased with contact time (up to $120 \mathrm{~min}$ ) and pressure (up to 1.27 bar). However, an overpressure of 4 bar caused a slight decrease in the solubilisation of the organic matter in the waste. The highest solubilisation, corresponding to a $\mathrm{COD}_{\mathrm{s}}$ of $13 \mathrm{~g} \mathrm{~L}^{-1}$ at the end of the pre-treatment, was observed in the assay with lime concentration of $0.2 \mathrm{~g} \mathrm{Ca}(\mathrm{OH})_{2} \mathrm{~g}^{-1}$ waste, at 1.27 bar and $90^{\circ} \mathrm{C}$, during $120 \mathrm{~min}$. Use of sodium hydroxide as chemical agent resulted in higher solubilisation of the organic matter (Table 3 ). Thermochemical hydrolysis with $0.2 \mathrm{~g} \mathrm{NaOH} \mathrm{g}^{-1}$ waste, at $1.27 \mathrm{bar}$ and $90{ }^{\circ} \mathrm{C}$ for $120 \mathrm{~min}$, yielded a soluble COD in the medium as high as $32 \mathrm{~g} \mathrm{~L}^{-1}$. Similarly to lime-catalyzed hydrolysis, COD solubilisation in sodium hydroxide pre-treatment tests improved with contact time, pressure and temperature.

Biodegradability tests of the mixed liquor resulting from pretreated wastes were done upon analysis of the soluble COD, and considering the highest yields obtained. Pre-treated wastes under three different conditions were selected, namely: $\mathrm{Ca}(\mathrm{OH})_{2}\left(90^{\circ} \mathrm{C} /\right.$ 1 bar and $90^{\circ} \mathrm{C} / 1.27$ bar) and $\mathrm{NaOH}\left(90^{\circ} \mathrm{C} / 1.27\right.$ bar $)$. Cumulative 
Table 3

Soluble COD $(\mathrm{g} / \mathrm{L})$ obtained after thermochemical pre-treatment of poultry litter.

\begin{tabular}{|c|c|c|c|c|c|c|c|}
\hline & & $\mathrm{Ca}(\mathrm{OH})_{2}$ & & & & $\mathrm{NaOH}$ & \\
\hline$t(\min )$ & {$\left[\mathrm{g} / \mathrm{g}_{\text {waste }}\right]$} & $\begin{array}{l}1.01 \text { bar } \\
20^{\circ} \mathrm{C}\end{array}$ & $\begin{array}{l}1.01 \text { bar } \\
90{ }^{\circ} \mathrm{C}\end{array}$ & $\begin{array}{l}1.27 \text { bar } \\
90^{\circ} \mathrm{C}\end{array}$ & $\begin{array}{l}4 \text { bar } \\
90{ }^{\circ} \mathrm{C}\end{array}$ & $\begin{array}{l}1.01 \text { bar } \\
20{ }^{\circ} \mathrm{C}\end{array}$ & $\begin{array}{l}1.27 \text { bar } \\
90^{\circ} \mathrm{C}\end{array}$ \\
\hline 30 & $\begin{array}{l}0.05 \\
0.1 \\
0.2\end{array}$ & $\begin{array}{l}3.77 \\
3.27 \\
3.20\end{array}$ & $\begin{array}{l}5.30 \\
5.18 \\
7.28\end{array}$ & $\begin{array}{l}9.08 \\
10.37 \\
9.31\end{array}$ & $\begin{array}{l}4.34 \\
8.74 \\
9.54\end{array}$ & $\begin{array}{l}9.62 \\
10.82 \\
13.78\end{array}$ & $\begin{array}{l}\text { nd } \\
\text { nd } \\
\text { nd }\end{array}$ \\
\hline 60 & $\begin{array}{l}0.05 \\
0.1 \\
0.2\end{array}$ & $\begin{array}{l}4.40 \\
4.27 \\
3.83\end{array}$ & $\begin{array}{l}9.43 \\
9.17 \\
9.13\end{array}$ & $\begin{array}{l}11.14 \\
10.90 \\
11.62\end{array}$ & $\begin{array}{l}10.34 \\
9.70 \\
9.64\end{array}$ & $\begin{array}{l}10.25 \\
11.85 \\
14.58\end{array}$ & $\begin{array}{l}14.82 \\
18.80 \\
21.32\end{array}$ \\
\hline 120 & $\begin{array}{l}0.05 \\
0.1 \\
0.2\end{array}$ & $\begin{array}{l}5.08 \\
5.35 \\
4.31\end{array}$ & $\begin{array}{l}10.90 \\
10.90 \\
10.51\end{array}$ & $\begin{array}{l}9.36 \\
9.52 \\
12.88\end{array}$ & $\begin{array}{l}9.92 \\
10.80 \\
11.52\end{array}$ & $\begin{array}{l}12.20 \\
14.52 \\
17.60\end{array}$ & $\begin{array}{l}16.80 \\
28.68 \\
32.02\end{array}$ \\
\hline
\end{tabular}

nd: Not determined.

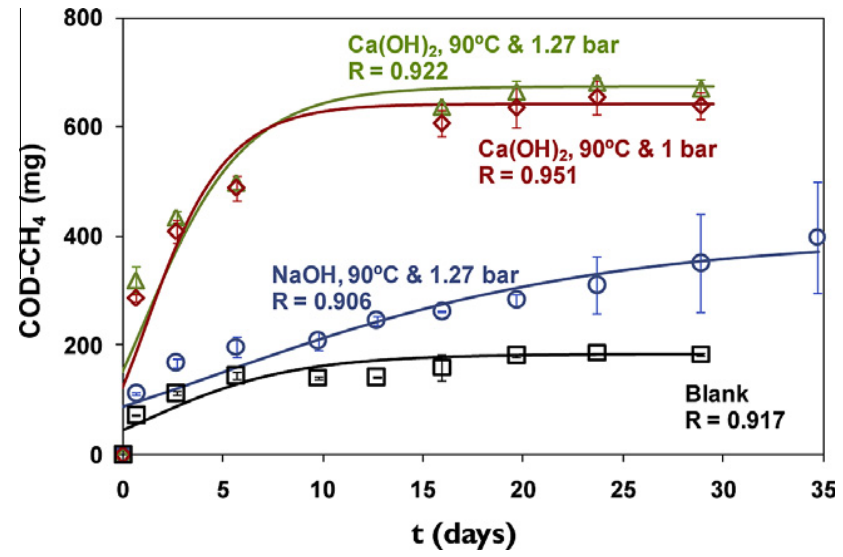

Fig. 3. Cumulative methane production $\left(\mathrm{mg} \mathrm{COD}-\mathrm{CH}_{4}\right)$ during anaerobic biodegradability tests of pre-treated poultry litter. Blank without waste ( $\square$ ), pre-treated with $\mathrm{Ca}(\mathrm{OH})_{2}$ at $90{ }^{\circ} \mathrm{C}$ and 1 bar $(\diamond) ; \mathrm{Ca}(\mathrm{OH})_{2}$ at $90{ }^{\circ} \mathrm{C}$ and $1.27 \operatorname{bar}(\triangle)$, and $\mathrm{NaOH}$ at $90{ }^{\circ} \mathrm{C}$ and 1.27 bar (O). The symbols represent the experimental data with respective standard deviation ( $n=3$ points). The lines represent the predicted data by the modified Gompertz equation.

methane production in these assays is displayed in Fig. 3. Methaneproduction parameters predicted by the modified Gompertz equation, relative methane production, solubilisation percentages, and soluble products formed during the anaerobic digestion of these mixed liquors are shown in Table 4.

Although soluble COD resulting from thermochemical pretreatment was higher when using sodium hydroxide, subsequent substrate conversion to methane was less effective in this case than in the tests subjected to pre-treatment with lime. Wu et al. (2009) observed that the addition of sodium hydroxide, at $131^{\circ} \mathrm{C}$, inhibited methane production from meat and bone meal. The high solubilisation observed during the pre-treatment with sodium hydroxide $\left(\mathrm{PS}_{\text {pre-treatment }}=56 \%\right.$ ) may have generated some metabolites, like VFA, ammonia, furfural, etc., which could be responsible for methanogenesis inhibition (Table 4). Zhang and Jahng (2010), concluded that lime was better effective than sodium hydroxide and potassium hydroxide in terms of volumetric methane production rates and removal of organic compounds from a piggery wastewater. The suggested reason was that the cations $\mathrm{Na}^{+}$and $\mathrm{K}^{+}$were strong methanogenic inhibitors when compared with $\mathrm{Ca}^{2+}$.

According to Chang et al. (1997), the optimal conditions for the alkaline pre-treatment of wheat straw were $2 \mathrm{~h}$ with a concentration of $0.1 \mathrm{~g} \mathrm{Ca}(\mathrm{OH})_{2} \mathrm{~g}^{-1}$ waste at $100-120^{\circ} \mathrm{C}$. Reducing sugars concentration five times higher than with untreated material were obtained. In the study by Rafique et al. (2010), an increase of $70 \%$
Table 4

Methane-production parameters predicted by the modified Gompertz equation and experimental results obtained at the end of the anaerobic biodegradability tests of poultry litter after thermochemical pre-treatment. The \% TS in the BMP assays after the pre-treatment was $2.5 \%$.

\begin{tabular}{|c|c|c|c|c|}
\hline & & $\begin{array}{l}\mathrm{Ca}(\mathrm{OH})_{2}, 90^{\circ} \mathrm{C} \\
\text { and } 1 \mathrm{bar}\end{array}$ & $\begin{array}{l}\mathrm{Ca}(\mathrm{OH})_{2} 90^{\circ} \mathrm{C} \\
\text { and } 1.27 \text { bar }\end{array}$ & $\begin{array}{l}\mathrm{NaOH}, 90^{\circ} \mathrm{C} \\
\text { and } 1.27 \text { bar }\end{array}$ \\
\hline $\mathrm{P}$ & $\mathrm{mg} \mathrm{COD}-\mathrm{CH}_{4}$ & $460 \pm 28$ & $490 \pm 15$ & $215 \pm 102$ \\
\hline BMP & $\mathrm{LCH}_{4} \mathrm{~kg}^{-1} \mathrm{VS}$ & $129 \pm 8$ & $137 \pm 4$ & $59 \pm 28$ \\
\hline $\mathrm{Rm}$ & $\mathrm{mg} \mathrm{COD}-\mathrm{CH}_{4} \mathrm{~d}^{-1}$ & 102.1 & 85.0 & 12.9 \\
\hline MP & $\%$ & $30 \pm 1$ & $32 \pm 1$ & $14 \pm 7$ \\
\hline $\mathrm{PS}_{\text {pre-treatment }}$ & $\%$ & 15 & 20 & 56 \\
\hline PS & $\%$ & $19 \pm 1$ & $16 \pm 1$ & $8 \pm 1$ \\
\hline $\mathrm{pH}$ & & 6.8 & 6.9 & 7.0 \\
\hline $\mathrm{COD}_{\mathrm{s}}$ & $\mathrm{g} \mathrm{L}^{-1}$ & $3.18 \pm 0.48$ & $3.20 \pm 0.42$ & $18.07 \pm 2.12$ \\
\hline Sugars & $\mathrm{g} \mathrm{L}^{-1}$ & $1.06 \pm 0.30$ & $0.74 \pm 0.13$ & $1.06 \pm 0.16$ \\
\hline $\mathrm{NH}_{4}^{+}-\mathrm{N}$ & $\mathrm{g} \mathrm{L}^{-1}$ & $0.58 \pm 0.08$ & $0.58 \pm 0.18$ & $0.69 \pm 0.08$ \\
\hline
\end{tabular}

Note: The values obtained in the blanks were subtracted in the data presented in the table.

in the methane yield was obtained after pre-treatment with $0.05 \mathrm{~g}$ $\mathrm{Ca}(\mathrm{OH})_{2} \mathrm{~g}^{-1}$ waste at $70{ }^{\circ} \mathrm{C}$. In the present study, comparing the two tests with lime, an increase in terms of absolute methane production, MP, and PS was observed with the higher pressure tested. In addition, the specific methane production was significantly $(P<0.01)$ higher in the test at 1.27 bar $\left(137 \pm 4 \mathrm{~L} \mathrm{CH}_{4} \mathrm{~kg}^{-1} \mathrm{VS}\right)$ (Table 4).

\section{Conclusions}

Biomethane potential of raw poultry litter ( $1 \% \mathrm{TS}, 0.72 \mathrm{~g}$ $\mathrm{VS}_{\text {inoculum }} \mathrm{g}^{-1} \mathrm{VS}_{\text {waste }}$ ) was $145 \pm 14 \mathrm{~L} \mathrm{CH}_{4} \mathrm{~kg}^{-1}$. The biological cotreatments and the thermochemical pre-treatments with lime and sodium hydroxide had a significant impact in the hydrolysis of poultry litter. Bioaugmentation with C. saccharolyticus caused $74 \pm 1 \%$ of waste solubilisation. However, the improvement in the substrate hydrolysis resulted in the accumulation of metabolites, such as VFA, which seemed to inhibit methanogenesis and impaired methane production. Therefore, separating hydrolysis from the subsequent steps in anaerobic digestion of poultry residues may be necessary to maximize its efficiency.

\section{Acknowledgements}

The authors acknowledge the financial support of the "Fundação para a Ciência e a Tecnologia" through the grant given to José Carlos Costa (SFRH/BDP/48962/2008), and to the "Fundo Europeu de Desenvolvimento Regional" through the project QREN 2008/2509. The authors would like to acknowledge Isabel Belo for the valuable 
help given with the high-pressure reactor used for waste physicochemical pre-treatment.

\section{References}

Alves, M.M., Mota Vieira, J.A., Álvares Pereira, R.M., Pereira, M.A., Mota, M., 2001 Effects of lipids and oleic acid on biomass development in anaerobic fixed bed reactors. Part I: Biofilm growth and activity. Water Research 35, 255-263.

Angelidaki, I., Alves, M.M., Bolzonella, D., Borzacconi, L., Campos, L., Guwy, A.J. Kalyuzhnyi, S., Jenicek, P., van Lier, J.B., 2009. Defining the biomethane potential (BMP) of solid organic wastes and energy crops: a proposed protocol for batch assays. Water Science and Technology 59 (5), 927-934.

APHA, AWWA and WPCF, 1998. Standard Methods for the Examination of Water and Wastewater, 17th ed. American Public Health Association, Washington, DC.

Bujoczek, G., Oleszkiewicz, J., Sparling, R., Cenkowski, S., 2000. High solid anaerobic digestion of chicken manure. Journal of Agricultural Engineering Research 76, 51-60.

Chang, V., Burr, B., Holtzapple, M., 1997. Lime pretreatment of switchgrass. Applied Biochemistry and Biotechnology 63-65, 3-19.

Chang, V., Nagwani, M., Kim, C., Holtzapple, M., 2001. Oxidative lime pretreatment of high-lignin biomass. Applied Biochemistry and Biotechnology 94, 1-27.

Colleran, E., Concannon, F., Goldem, T., Geoghegan, F., Crumlish, B., Killilea, E. Henry, M., Coates, J., 1992. Use of methanogenic activity tests to characterize anaerobic sludges, screen for anaerobic biodegradability and determine toxicity thresholds against individual anaerobic tropic groups and species. Water Science and Technology 25, 31-40.

Fernandes, T.V., Klaasse Bos, G.J., Zeeman, G., Sanders, J.P.M., van Lier, J.B., 2009. Effects of thermo-chemical pre-treatment on anaerobic biodegradability and hydrolysis of lignocellulosic biomass. Bioresource Technology 100, 2575-2579.

Kelleher, B., Leahy, J., Henihan, A., ÓDwyer, T., Suuton, D., Leahy, M., 2002. Advances in poultry litter disposal technology - a review. Bioresource Technology 83, 2736.

Lynd, L.R., Grethlein, H.E., Wolkin, R.H., 1989. Fermentation of cellulosic substrates in batch and continuous culture by Clostridium thermocellum. Applied and Environmental Microbiology 55, 3131-3139.

Miller, G.L., 1959. Use of dinitrosalicylic acid reagent for determination of reducing sugar. Analytical Chemistry 31 (3), 426-428.

Molinuevo-Salces, B., García-González, M.C., González-Fernández, C., Cuetos, M.J., Morán, A., Gómez, X., 2010. Anaerobic co-digestion of livestock wastes with vegetable processing wastes: a statistical analysis. Bioresource Technology 101 9479-9485.
Mosier, N., Wyman, C., Dale, B., Elander, R., Lee, Y., Holtzapple, M., Ladisch, M., 2005 Features of promising technologies for pretreatment of lignocellulosic biomass. Bioresource Technology 93, 673-686.

Pavlostathis, S.G., Giraldo-Gomez, E., 1991. Kinetics of anaerobic treatment. Water Science and Technology 24, 35-59.

Petitdemange, E., Caillet, F., Giallo, J., Gaudin, C., 1984. Clostridium cellulolyticum sp. nov., a cellulolytic, mesophilic: species from decayed grass. International Journal of Systematic Bacteriology 34, 155-159.

Rafique, R., Poulsen, T., Nizami, A., Asam, Z., Murphy, J., Kiely, G., 2010. Effect of thermal, chemical and thermo-chemical pre-treatments to enhance methane production. Energy 35, 4556-4561.

Rao, A.G., Reddy, T.S.K., Prakash, S.S., Vanajakshi, J., Joseph, J., Jetty, A., Reddy, A.R. Sarma, P.N., 2008. Biomethanation of poultry litter leachate in UASB reactor coupled with ammonia stripper for enhancement of overall performance. Bioresource Technology 99, 8679-8684.

Rao, A.G., Prakash, S.S., Joseph, J., Reddy, A.R., Sarma, P.N., 2011. Multi stage high rate biomethanation of poultry litter with self mixed anaerobic digester. Bioresource Technology 102, 729-735.

Singh, K., Lee, K., Worley, J., Risse, L.M., Das, K.C., 2010. Anaerobic digestion of poultry litter: a review. Applied Engineering in Agriculture 26 (4), 677688.

Sun, Y., Cheng, J., 2002. Hydrolysis of lignocellulosic materials for ethanol production: a review. Bioresource Technology 83, 1-11.

VanFossen, A.L., Verhaart, M.R.A., Kengen, S.M.W., Kelly, R.M., 2009. Carbohydrate utilization patterns for the extremely thermophilic bacterium Caldicellulosiruptor saccharolyticus reveal broad growth substrate preferences. Applied and Environmental Microbiology 75 (24), 7718-7724.

Webb, A.R., Hawkes, F.R., 1985. Laboratory scale anaerobic digestion of poultry litter: gas yield-loading rate relationship. Agricultural Wastes 13 (1), 3149.

Weimer, P., Zeikus, J., 1977. Fermentation of cellulose and cellobiose by Clostridium thermocellum in the absence and presence of Methanobacterium thermoautotrophicum. Applied Biochemistry and Biotechnology 33, 289-297.

Wu, G., Hu, Z., Healy, M.G., Zhan, X., 2009. Thermochemical pretreatment of meat and bone meal and its effect on methane production. Frontiers of Environmental Science and Engineering in China 3 (3), 300-306.

Zhang, L., Jahng, D., 2010. Enhanced anaerobic digestion of piggery wastewater by ammonia stripping - effects of alkali types. Journal of Hazardous Materials 182, 536-543.

Zwietering, M.H., Jongenburger, I., Rombouts, F.M., van't Riet, K., 1990. Modeling of the bacterial growth curve. Applied and Environmental Microbiology 56 (6), 1875-1881. 